\title{
STUDENTS' GENERATED QUESTION QUALITY THROUGH STEM BASED PROJECT LEARNING IN SCIENCE ACTIVITY
}

\author{
Annisa Nurramadhani ${ }^{\left.a^{*}\right)}$, Irvan Permana ${ }^{a)}$ \\ a) Universitas Pakuan, Bogor, Indonesia \\ ${ }^{*}$ Corresponding Author: annnisanurramadhani@unpak.ac.id
}

Article history: received 06 May 2020; revised 20 May 2020; accepted 30 July 2020

\begin{abstract}
STEM based project learning also capable triggering student to express another higher order thinking skill, such as inquiry by posing question. Generating questions, making comparisons, dealing with contradictions, and scientific inquiry skills are an example of cognitive activities that are classified as higher-order thinking skills. Those skills are including in $21^{\mathrm{st}}$ century skills that needed by the students to face the workspaces demanding in this revolution industry 4.0 and future. The purposes of this research is to investigate students' question quality through STEM based project learning in science activity. The method that is used in this research is descriptive. The subject in this research are the students of preservice teacher biology and science education for about 21 students. The research needs an analysis of students' generated question quality when they are in basic physics laboratory activity. This laboratory activity used STEM based project learning approach with reading assignment in the early meeting before each laboratory activity. The technique to take the data that is used in this research are video recording, observation, and informal interview. The research instrument to take the data that is used are observation sheet for student's generated question quality. The result of this research is from the science laboratory activity, students' generated question quality that has the most are understanding and relationship which is in the beginning of open question quality and information category gained lower than both of category. It means that, students promoting the improvement of their question quality. It also proved that evaluating, finding and solution category has expressed by the students in both of laboratory activities. It can be concluded that that the quality of students generated question has slightly improved to open question quality through STEM based project learning in science activity.
\end{abstract}

Keywords: STEM education; science learning; generating question; project based learning

\section{INTRODUCTION}

STEM education is one of the approaches, learning model, learning method that is used in this era lately. Most of schools in Indonesia or around the world have implemented this new Science, Technology, Engineering, and Math (STEM) education program that will introduce students to a number of STEM concepts in the school curriculum. In this era of curriculum, considerable attention is being focused on curriculum integration. The inquiry is one aspect of alteration teaching and learning on curriculum integration that involves activity and skills which has developed several learning principles and methods of instruction [1]. STEM education is integrated learning by using science concept, technology, engineering, and mathematics combine together to improve student's motivation, some skills such as critical thinking, creative thinking, problem solving skills, and all the skills that is include in 21 st century skills. The purposes of STEM education in science learning are to motivate students promoting practice using integrated skills to solve problems and become meaningful learning [2,3,4]. STEM also can generate students as innovator, inventor, logical thinker, problem solver, technological literate and someone who capable of using technology in their life and relate with their own culture $[5,6]$. This revolution industry 4.0 era, the outcome of students for workspaces demanding need those skills. So, the education must have changed the learning purposes for students become they reach the higher order thinking ability and hands on ability by the STEM education approaches. Integrative STEM education is also very effective way to engage students in higher-order critical thinking and problem-solving skills through mathematics and science in the context of technology and engineering.

STEM based project learning has influenced students' performances positively. Students who have already experienced with STEM based project learning showed positive attitudes toward learning, capable to overcome team communication, and collaborative behavior $[7,8,9,10]$. STEM based project learning also can develop students' interest, self-confidence, and self-efficacy [11], which was related to the components of STEM based project learning such as collaborations in group and contextual problems related to the students' real-world experiences. Moreover, students who studied and take STEM based project learning class were success in courses and school [7]. In addition, beside non-academic performance, components of STEM based project learning were highly improve students' academic achievement. Researcher [8] found that hands-on activities and field-based contexts make positive effects for students in content knowledge and attitude toward learning. Furthermore, students encouraged through STEM based project learning learning are required to solve problems embedded in the project which improved their problemsolving skills that is include in higher order thinking skills $[12,13]$. So, that STEM based project learning also capable 
triggering student to express another higher order thinking skill, such as inquiry by posing question. Constructing arguments, generating questions, making comparisons, dealing with contradictions, and scientific inquiry skills are an example of cognitive activities that are classified as higher-order thinking skills [14]. For students to be active learners and independent thinkers, they must generate questions which is shape, focus, and guide their thinking in learning especially in science learning [15].

However, in reality most of students less express their inquiry or less for posing question. Based on research [16], the quality of students posing question still low or it can be said that the students' generated question quality is in closed question quality category. However, many students have stopped asking questions, and they do not articulate a desire to discover, debate, or challenge [17]. Even tough, question skill is one of the 21 st century skills that is needed by the students. Question skills are the indicator of students who has critical thinking and curiosity which is the basic skills in learning science. Actually, learning is most likely occurred in contexts where individuals are allowed to construct and build their knowledge based on their learning experiences that they have been exposed [18,19]. So, students express their question is an indicator that learning is successful to build student construct their concept. Based on that statement, in this research the laboratory activity especially in science learning through STEM based project learning are implemented to construct and improve students question quality.

\section{RESEARCH METHODS}

The method that is used in this research is descriptive. The subject in this research are the students of preservice teacher biology and science education for about 21 students. Students are divided into 4 heterogenous group. Each group consist of 5 until 6 students. The research needs an analysis of students' generated question quality when they are in basic physics laboratory activity. This laboratory activity used STEM based project learning approach with reading assignment in the early meeting before each laboratory activity. This laboratory activity conducted in three meetings for each project. There are reading at home and the rest activity done at classroom (designing, making, and testing). The project that have already done by the students are "Sailor boat" and "Let's fun with music". The stages of this laboratory activity are used modification design learning in each project from The Steps of Engineering Design Process based on [20], such as described in table I. While, the technique to take the data that is used in this research are video recording, observation, and informal interview. The research instrument to take the data that is used are observation sheet for student's generated question quality that has category or classification of questions quality according to [21] described in table II.

TABLE I. DESCRIPTION OF LEARNING STAGES

\begin{tabular}{|c|c|c|}
\hline Stages & Description & Aspect \\
\hline Reading & $\begin{array}{l}\text { Students reading all the science concept related to the project that they will be } \\
\text { created in the classroom }\end{array}$ & Science \\
\hline \multirow[t]{4}{*}{ Designing } & Students design the prototype project based on science concept from each problem & Science \\
\hline & $\begin{array}{l}\text { Students design the prototype project with consideration of how to construct the } \\
\text { prototype, what material that is used? why we use those material? }\end{array}$ & Engineering \\
\hline & $\begin{array}{l}\text { Students design the prototype project with consideration of what tools and the } \\
\text { technique to construct the prototype? The modern one or the traditional one? }\end{array}$ & Technology \\
\hline & $\begin{array}{l}\text { Students design the prototype project with consideration the size, length, } \\
\text { calculations to make it perfect and useful project }\end{array}$ & Mathematics \\
\hline Presentation & $\begin{array}{l}\text { Students present the design in front of their friends and revise the design based on } \\
\text { the advises from their friends. }\end{array}$ & \\
\hline \multirow[t]{2}{*}{ Making } & $\begin{array}{l}\text { Students construct the prototype project using the material that has been decided in } \\
\text { designing stages. }\end{array}$ & Engineering \\
\hline & $\begin{array}{l}\text { Students construct the prototype project using the technique that has been decided } \\
\text { in designing stages. }\end{array}$ & Technology \\
\hline $\begin{array}{l}\text { Testing and } \\
\text { Communicating }\end{array}$ & Students present their prototype project in front of their friends. & \\
\hline
\end{tabular}


TABLE.II QUESTION QUALITY CATEGORY

\begin{tabular}{|c|c|c|c|}
\hline $\begin{array}{l}\text { Question } \\
\text { Quality }\end{array}$ & Category & Description & Question Type \\
\hline \multirow{5}{*}{$\begin{array}{l}\text { Closed } \\
\text { Question } \\
\text { (Low Level) }\end{array}$} & \multirow[t]{3}{*}{ Information } & Questioning about information or fact & What...? \\
\hline & & Direct and simple answer with only 'yes or no' answer. & Where...? \\
\hline & & & Which...? \\
\hline & \multirow[t]{2}{*}{ Understanding } & $\begin{array}{l}\text { Question that need explanation which help students get their } \\
\text { concept, fact, phenomena, task, and procedure. }\end{array}$ & Why...? \\
\hline & & There is no direct and simple answer. & How...? \\
\hline \multirow[t]{7}{*}{$\begin{array}{l}\text { Open Question } \\
\text { (High Level) }\end{array}$} & \multirow[t]{2}{*}{ Relationship } & $\begin{array}{l}\text { The purposes of question are to comprehended the causes and } \\
\text { consequences. }\end{array}$ & $\begin{array}{l}\text { Which } \\
\text { consequences..? }\end{array}$ \\
\hline & & Question has relationship with two or more concepts. & $\begin{array}{l}\text { Which differences...? } \\
\text { What happen...? }\end{array}$ \\
\hline & \multirow[t]{3}{*}{ Evaluation } & $\begin{array}{l}\text { Students try to find the guide to make a decision or express their } \\
\text { personal opinion. }\end{array}$ & Which is the best...? \\
\hline & & $\begin{array}{l}\text { This question shows students' point of view, their choices, and } \\
\text { judgement for a problem. }\end{array}$ & $\begin{array}{l}\text { What is opinion...? } \\
\text { What do we think }\end{array}$ \\
\hline & & & about...? \\
\hline & \multirow{2}{*}{$\begin{array}{l}\text { Finding and } \\
\text { Solution }\end{array}$} & The question purposes are to comprehended a complex problem & What if..? \\
\hline & & $\begin{array}{l}\text { The answer is related with identification or solution from a } \\
\text { problem. }\end{array}$ & if...then.... \\
\hline
\end{tabular}

\section{RESULTS AND DISCUSSION}

The results of students' generated questions quality from the laboratory activity through STEM based project learning is described briefly in figure below.

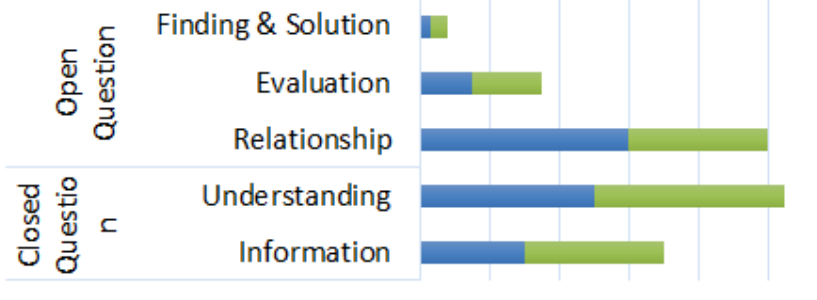

$$
\begin{array}{lllllll}
0 & 20 & 40 & 60 & 80 & 100 & 120
\end{array}
$$

- Project 1 Project 2

Figure 1. The Results of Students Generated Question Quality Through STEM based Learning Laboratory Activity

The data shows that students generated question quality has an improvement from the first project (Sailor boat) to the second one (Let's fun with music) for all aspect question category. Nevertheless, understanding and relationship category that has the most expressed by the student during the activity in both of projects. Understanding category in first project $(n=50)$ and second project $(n=55)$, while relationship category gain in the first project $(n=60)$ and second project $(\mathrm{n}=70)$. This data taken the most from students when they design and making the project among their groups. It can be said that students more expressed about the consequences, the differences, and what will happen next. This will appear when students get the handson activities with some challenge's things. This project use STEM (science, engineering, technology, and mathematics) approaches, so this laboratory activity makes them curious and it could be triggering the students to generated question in open question category. It also supported by the data of information category $(n=15, n=20)$ that has lower amount than understanding and relationship category. Although in evaluation and finding solution category as not much as understanding and relationship category. It means students' generated question quality are beginning to improved rather than using the usual method of learning, such as lecturing [16].

For more detail data, it will show the type of question from each category in every project that has already done by the students.

From data above, there are some of quality of question at learning stages in laboratory activity with STEM based project learning from both projects. The open question category expressed by the students almost in stages making, testing and communicating. Every stage has the question quality category, but it expressed from the closed question quality to open question quality in a line with the learning stages. The question quality improved from both of project because the students learn science through STEM based project. Based on [19] another concept student question generation is meta-cognition. Meta-cognitive emphasizes the role processes, such as planning, monitoring, predicting, evaluating and revising. All the activity that is include in meta-cognitive role are consisting in STEM based project learning. The students also triggering their critical thinking, creative thinking, and curiosity, so that they posed their question with vary quality. It is in a line with the research 
TABLE III. DESCRIPTION OF STUDENTS' QUESTION QUALITY CATEGORY AND LEARNING STAGES

\begin{tabular}{|c|c|c|c|c|}
\hline Stages & Question Type (1 ${ }^{\text {st }}$ Project) & $\begin{array}{l}\text { Question } \\
\text { Category }\end{array}$ & Question Type (2 ${ }^{\text {nd }}$ Project) & $\begin{array}{l}\text { Question } \\
\text { Category }\end{array}$ \\
\hline Reading & $\begin{array}{l}\text { How the Archimedes Law and } \\
\text { Density applied in making of boat? }\end{array}$ & Understanding & $\begin{array}{l}\text { What is the differences amplitude } \\
\text { and frequency? Then the } \\
\text { differences between timbre and } \\
\text { pitch? }\end{array}$ & information \\
\hline Designing & $\begin{array}{l}\text { Why we use styrofoam and what will } \\
\text { happen if we use plastic bottle for boat } \\
\text { body? }\end{array}$ & Relationship & $\begin{array}{l}\text { How the sound be like if we use } \\
\text { big can and small can? }\end{array}$ & Understanding \\
\hline Presentation & Why the propeller moves backward? & Understanding & $\begin{array}{l}\text { Why the bottle is not filled by } \\
\text { water? Is there any effect to the } \\
\text { sound? }\end{array}$ & Understanding \\
\hline Making & $\begin{array}{l}\text { Which one do you think, we use } \\
\text { empty plastic bottle as a outrigger } \\
\text { (stabilixer) or we do not use it to carry } \\
\text { out differentliquid? }\end{array}$ & Evaluation & $\begin{array}{l}\text { If we try to changes the water } \\
\text { with gravel, is there any effect to } \\
\text { the sound? How is be like? Or we } \\
\text { just add the water to make C } \\
\text { tone? }\end{array}$ & $\begin{array}{l}\text { Finding and } \\
\text { Solution }\end{array}$ \\
\hline $\begin{array}{l}\text { Testing and } \\
\text { Communica } \\
\text { ting }\end{array}$ & $\begin{array}{l}\text { If we try to put the rubber out, how is } \\
\text { the propeller movement? Is it still } \\
\text { backward? }\end{array}$ & $\begin{array}{l}\text { Finding and } \\
\text { Solution }\end{array}$ & $\begin{array}{l}\text { How about we add broom stick in } \\
\text { ensemble, what is going on with } \\
\text { the sound composition in } \\
\text { ensemble? }\end{array}$ & Evaluation \\
\hline
\end{tabular}

from [22,14], the formation of a good question is a creative act, critical, curious all about science, engineering, and mathematics that is include in higher order thinking skills. Questions also help learners to make understanding what has been taught and to construct meaning from the data and information that has been given during the activity in learning.

The project that has been done by the students are Sailor boat (1st project) and Let's fun with music (2nd project). Sailor boat is the project that ask students to create a boat that can sail with carry out the different liquid and different density. While, Let's fun with music is the project that ask the students to create their own musical instrument from waste things, for instance plastic bottle, glass bottle, can, or something else that can produce sound. After that they should present their own musical instrument with the song and attract their friends. To determine the tone, students use Da Tune application that has been downloaded from play store. Before all the things have been done, students should read the theory that relate with the project. After they read, they have to had a question to posed to their teacher or friends. They can read the theory or something else pertaining the project from any platform, either online or offline like text book, encyclopedia, science magazine.

From the reading treatment, it is shown the novel results that it can trigger students to ask any questions that they want to know. In a line with the research that shown informational science text can provide, triggering, and make students' interest in science concept, give students' chance to review science words, concept, and promoting the construction of science practice in their everyday life [23]. Reading also can enrich students' concept before they do the activity. As survey that has been done during the learning, some of students said that when they read the concept, they more ready to face the activity in tomorrow learning. Even more, science is not only the concept or theory but also fact and application in daily life. Thus, students should know the basic concept that relate in their project which is they can find in their daily life. But, the obstacle in the students learning is in the first meeting, they are look like shy to express their question. It is proven from the data that in the first project the number of student's questions are less than second project. They are not used to posed question. It is in a line with the result of informal interview from several students, $80 \%$ student's shay to posed question directly because they afraid the lecturer or teacher will mad of them and also their friends will be laughing at them. So that, in this learning, the environment of STEM based project make the students express their question freely without hesitation.

\section{CONCLUSION}

It can be concluded from the research is STEM based project learning with reading in early meeting can improve students question quality. The greatest number of question quality category in first and second project are understanding and relationship. The STEM based project learning also can make students express the evaluation, finding and solution category. It means that the quality of students generated question has slightly improved to open question quality through STEM based project learning in science activity.

Acknowledgements

We thank to LPPM UNPAK that has funding this research, so that this research run very well. I also thank to Science Education Study Program UNPAK team who gave us an opportunity, courage, and advices during the research. 


\section{REFERENCES}

[1] Setiawaty,et.al. 2017. Science, Technology, Engineering, and Mathematics (STEM) Learning on Students' Science Process Skills and Science Attitudes. Emerald Research Proceeding Series. 1:575-581.

[2] Wai, J., Lubinski, D., Benbow, C. P., \& Steiger, J. H 2010. Accomplishment in Science, Technology, Engineering, and Mathematics (STEM) and Its Relation to STEM Educational Dose: A 25-Year Longitudinal Study. Journal of Educational Psychology, 102(4), 860-871. Retrieved from EBSCOhost.

[3] Leon, J, Nunez, J, L., \& Liew, J. 2015. Selfdetermination and STEM Education: Effect of Autonomy, Motivation, and Self-regulated Learning on High School Math Achievement. Learning and Individual Differences. Retrieved: journal homepage: www.elsevier.com/locate/lindif.

science.eu/c/document_library/get_file?uuid=3252e8 5a-125c-49c2-a090-eaeb3130737a\&groupId=10136

[4] Moore TJ.; Glancy AW.; Tank, KM, Kersten, JA, Smith KA, and Stohlmann MS. 2014. A framework for quality k-12 engineering education: Research and development. (J-PEER), 4 (2). "PDCA12-70 data sheet," Opto Speed SA, Mezzovico, Switzerland.

[5] Stohlmann, M.; Moore, T. J.; \& Roehrig, G. H. 2012. Considerations for Teaching Integrated STEM Education. Journal of Pre-College Engineering Education Research (J-PEER), 2 (1), 4.

[6] Morrison, J. 2006, Attributes of STEM Education: The Student, The School, The Classroom [Monograph]. Baltimore, MD: Teaching Institute for Excellence in STEM, available at: http://www.tiesteach.org.

[7] Domínguez, C. \& Jaime, A. 2010. Database design learning: A project-based approach organized through a course management system. Computers \& Education, 55(3), 1312-1320.

[8] Kaldi, S., Filippatou, D. \& Govaris, C. 2011. Projectbased learning in primary schools: Effects on pupils' learning and attitudes. Education 3-13, 39(1), 35-47.

[9] Van Rooij, S. W. 2009. Scaffolding project-based learning with the project management body of knowledge (PMBOK®). Computers \& Education, 52(1), 210-219.

[10] Veenman, S., Kenter, B. \& Post, K. 2000. Cooperative learning in Dutch primary classrooms. Educational Studies, 26(3), 281-302. doi:10.1080/03055690050137114.

[11] Baran, M. \& Maskan, A. 2010. The effect of projectbased learning on pre-service physics teachers' electrostatic achievements. Cypriot Journal of Educational Sciences, 5(4), 243-257.

[12] Barron, B. J. S., Schwartz, D. L., Vye, N. J., Moore, A., Petrosino, A., Zech, L.,Bransford, J. D. \& The Cognition and Technology Group at Vanderbilt. 1998.
Doing with understanding: Lessons from research on problem- and project-based learning. The Journal of the Learning Sciences, 7(3\&4), 271-311.

[13] Boaler, J. 1997. Experiencing school mathematics: Teaching styles, sex, and settings. Buckingham: Open University Press.

[14] Zohar, A. \& Dori, Y.J. 2003. Higher order thinking skills and low achieving students: Are they mutually exclusive? The Journal of the Learning Sciences, 12, 145-182.

[15] Kaberman, Z \& Dori, Y, J. 2009. Question Posing, Inquiry, And Modeling Skills Of Chemistry Students In The Case-Based Computerized Laboratory Environment. International Journal of Science and Mathematics Education. 7:597-625.

[16] Nurramadhani, A. 2019. Profil Kualitas Keterampilan Bertanya Mahasiswa Calon Guru Dalam Pembelajaran Sains. Pedagonal: Jurnal Ilmiah Pendidikan. 3 (2): 01-09.

[17] Becker, R. 2000. The critical role of students' questions in literacy development. The Educational Forum, 64, 261-271.

[18] Bodner, G. M.; Klobucher, M. \& Geelan, D. R. 2001. The many forms of constructivism, Journal of Chemical Education, 78(8) 1107.

[19] Yu, F.Tsai, H. \& Wu, H. 2013. Effect of online procedural scaffolds and the timing of scaffolding provision on elementary Taiwanese students'question-generation, 56(2).484-494.

[20] Hynes, M., Portsmore, M., Dare, E., Milto, E., Rogers, C., Hammer, D. and Carberry, A. 2011. Infusing Engineering Design into High School STEM Courses. Retrieved from http://ncete.org/flash/pdfs/Infusing\%20Engineering\% 20Hynes.pdf.

[21] Cautinho,M,J., dan Almeida,P,A.2014. Promoting Student Questioning in The Learning of Natural Science. Procedia-Social and Behavioral Science. 3781-3785.

[22] Chin, C. 2002. Student generated questions: Encouraging inquisitive minds in learning. Science Teaching and Learning, 23(1), 59-67.

[23] Mantzicopoulos, P \& Patrick, H. 2013. Reading Picture Books and Learning Science: Engaging Young Children with Informational Text. Theory into Practice. 50: 269-276. 